4. Крушельницька О. В., Мельничук Д. П. Управління персоналом: навчальний посібник. К. : Кондор, 2003. 296 с.

5. Малиновський В.Я. Державна служба: теорія та практика: навч. Посібник. К. : Атіка, 2003. 160 с.

6. Серьогін С., Хлуткова В. Організація кар'єри державного службовця як засіб попередження і запобігання корупції. Вісник УАДУ. К. : УАДУ, 1999.

7. Ткач Р.В. Поняття професійної кар'єри у психології менеджменту, іiі види та динаміка розвитку: Ресурс доступу. http://www.bdpu.org/scientific_published /psychology_2 _2005/15.

DOI https://doi.org/10.30525/978-9934-26-005-6-12

\title{
ПРОЦЕС ЦИФРОВІЗАЦІї ДЕРЖАВНОГО УПРАВЛІННЯ В УКРАЇНІ
}

\author{
Мартиновська Д. В. \\ студентка IV курсу факультету права \\ ВНЗ «Університет імені Альфреда Нобеля» \\ м. Дніпро, Україна
}

У сучасному світі цифрові та інформаційні технології поглинають все більше і більше сфер суспільного життя. Сьогодні більшість країн Європи орієнтується на розвиток та впровадження цифрових методів державного управління, що робить ці методи та надання послуг більш розвиненими та сучасними, тим самим створюючи конкурентні переваги серед інших країн та займаючи лідируючи позиції. Серед таких країн можна виділити Фінляндію, Норвегію, Швецію, Данію, Нідерланди, Люксембург. Але, саме Естонію вважають взірцем цифровізації держави в Європі, оскільки 99\% державноадміністративних послуг там надаються онлайн.

Зараз Україна почала проводити низку реформ, важливу роль в яких відіграють реформи в системі державного 
управління, що передбачають певні заходи організаційного й нормативно-правового характеру, які спрямовані на осучаснення системи державної служби. Останні інформаційні технології помітно змінили усі суспільні відносини, перетворюючи нас на нове, технологічне, а головне - цифрове суспільство.

Одним 3 важливих елементів реформування держави в умовах цифрових перетворень - це електронне управління, поліпшення ефективності роботи державних органів 3 громадянами, підприємствами, організаціями та установами, що значно зменшить спільні затрати коштів та часу.

Термін «діджиталізація» $є$ неологізмом у нашій країні, він пояснюється як запровадження цифрових технологій у певні сфери, для оптимізації основних процесів. Саме «оптимізація» $є$ ключовим та найбільш вигідним варіантом, оскільки не потребує перебудови вже існуючих механізмів державного управління, а лише вдосконалює їх.

Серед переваг запровадження цифрових реформ в країнах $\epsilon$ те, що перші результати ми можемо спостерігати та використовувати у повсякденному житті вже зараз, адже дуже часто процес втілення нових методів в державне управління зазвичай потребує значного часу. Впровадження діджиталізації в країні відкриває для людей нові знання, навички та можливості, що сприяють створенню нових «продуктів», індустрій, систем та процесів загального використання. Цифрові перетворення у сфері публічного управління та адміністрування створюють перспективи для відкриття нових ринків та кампаній, а також залучення інвестицій, які впливають на конкурентоспроможність серед інших країн.

Для інтенсивного розвитку цифровізації в Україні у державному управлінні у 2019 році було створено Міністерство цифрової трансформації, яке забезпечує формування та реалізацію державної політики у сферах цифровізації, цифрового розвитку, цифрової економіки, цифрових інновацій, електронного управління, електронної демократії, розвитку інформаційного суспільства, інформатизації.

Основна мета Міністерства - реалізація проекту «Цифрова держава», яке об'єднає всі державні органи та відомства в єдину 58 
зручну і дієву онлайн-систему «Дія». Сьогодні портал «Дія» представлений як веб-сайт та мобільний додаток, що дає змогу зручно використовувати себе будь-якому громадянину нашої країни. Лише за рік свого існування цей портал відцифрував та увібрав у себе майже 30 державних послуг, які надаються не лише для громадян, а й для бізнесу [1]. Одна 3 переваг запровадження цифрової реформи у державні органи об'єднання декількох державних послуг в одну, зручність та незалежність від місця знаходження, а головне - економія часу.

Проте, хочу зауважити на тому, що усі державні дії та послуги, які надаються і здійснюються таким цифровим засобом, в першу чергу, повинні бути законодавчо затверджені. Друга перевага полягає в тому, що новітні технології та цифровізація мають важливе значення для мінімізації корупції в державі або, навіть, повне іiі подолання. Паперова бюрократія дуже часто робить процедуру отримання послуги складною та сприяє корупиіï. Наприклад, комп'ютеру дати хабар дуже важко, адже не можна підсунути йому гроші в конверті та сказати: «Зроби швидше». Це не спрацює.

Завдяки впровадженню порталу та відкритих даних ми маємо змогу спостерігати за прозорістю діянь державних органів, певним чином контролюючи їх діяльність та економити кошти на цих послугах, що виділяють 3 наших податків. Саме так Україна потрапила в ТОП-30 країн із 115-ти в загальному рейтингу з відкритих даних Open Data Barometer за 2017 рік; отримала 43-те місце із 126 у рейтингу найбільш інноваційних країн відповідно до Global Innovation Index 2018 (+7 позицій 3 2017 року) [3].

Для постійного розвитку механізмів публічного управління та адміністрування потрібна постійна підтримка та заохочення для вдосконалення 3 боку держави. Саме тут і постають дві найголовніші проблеми цифрових реформ: цифрова компетенція державних службовців та цифрова грамотність населення. Першими зіткнулися із проблемою саме службовці, які тепер повинні володіти навичками до використання цифрових технологій, не маючи цифрової освіти. Таку необхідність володіння цифровими навичками можна пояснити тим, що 
державні службовці $є$ основними користувачами державних цифрових додатків і відповідно до цього, цифрова грамотність тепер є однією з необхідних вимог для державної служби.

Друга проблема полягає в тому, що населення не має знань для користування новими цифровими реформами. Навчити громадян можна за допомогою спеціальних курсів або створення загальнонаціональних та загальнодоступних програм, які можна впровадити на початковій, середній або вищій освіті для усіх. За результатами першого дослідження по цифровій грамотності населення, проведеного Міністерством цифрової трансформації наприкінці 2019 року, 53\% українців не мають базового рівня цифрових навиків, а 15\% 3 них у віці 60-70 років не мають цифрових навичок взагалі [2].

На прикладі Євросоюзу хочу зазначити те, що ще у 2006 році вони визначили цифрову грамотність однією 3 8-ми ключових компетенцій, які повинен мати кожен європейський громадянин. Я також вважаю, що у сучасному світі цифрова грамотність громадян у державі $€$ необхідною навичкою для подальшого стрімкого розвитку самої держави. Саме тому, я би порекомендувала державним органам звернути увагу на міжнародний досвід та кращі практики впровадження IT-платформ в розвинених державах та запровадити соціальні програми для навчання населення.

Після вирішення основних проблем щодо цифрової грамотності я би почала розв'язувати питання про розвиток інфраструктури кібербезпеки держави та побудову сучасної телекомунікаційної інфраструктури доступу до мережі Інтернет і створення рівних умов такого доступу для різноманітних верств населення (наприклад, міських та сільських жителів), щоб людям не потрібно було йти до нотаріуса чи реєстраційної установи, а можна було б отримати послугу 3 вдома. Саме доступність послуг та безпека інформації для кожного $-\epsilon$ ключовим фактором у цифровій державі.

Враховуючи усе вище перераховане, я вважаю запровадження цифрових технологій в державній службі новим необхідним явищем сучасності, що невідворотно повинно втілюватися в усіх сферах діяльності людей. Вже сьогодні ми 60 
можемо спостерігати, що сфера публічного управління та державних органів одна із перших вже почала свій процес цифровізації, що потребує своєчасного вирішення питання щодо цифрової грамотності державних службовців та населення. Подальші цифрові трансформації в сферах державного адміністрування допоможуть країні розвиватися зі значними темпами, а для цього Україні повинна орієнтуватися на міжнародне та європейське співробітництво 3 метою інтеграції України до СС, виходу на європейський і світовий ринок.

\section{Література:}

1. Офіційний веб-сайт сервісу «Дія» URL: https://osvita.diia.gov.ua/ (дата звернення 07.11.2020)

2. Звіт уряду: як Мінцифра навчає українців цифровій грамотності // Прес-офіс Мінцифри від 21.02.2020 URL: https://thedigital.gov.ua/news/zvit-uryadu-yak-mintsifra-navchaeukraintsiv-tsifrovoi-gramotnosti (дата звернення 07.11.2020)

3. Олександр Саєнко: Діджиталізація державного управління та інноваційні технології - найпотужніші інструменти подолання корупції від 29.11.2018 URL:https://www.kmu.gov.ua/news/oleksandr-sayenkodidzhitalizaciya-derzhavnogo-upravlinnya-ta-innovacijni-tehnologiyinajpotuzhnishi-instrumenti-podolannya-korupciyi (дата звернення 07.11.2020) 